\title{
Brain Metastasis in a Patient with Malignant Melanoma: Melanotic Pattern
}

\author{
Malign Melanomlu Olguda Beyin Metastazı: Melanotik Patern
}

\author{
Özge Arıcı Düz11, Nesrin Helvacı Yılmaz¹, Erkingül Birday1, Gülhan Akan², Ahmet Bilici3 \\ ${ }^{1}$ Istanbul Medipol University Faculty of Medicine, Department of Neurology, Istanbul, Turkey \\ 2Istanbul Medipol University Faculty of Medicine, Department of Radiology, Istanbul, Turkey \\ 3Istanbul Medipol University Faculty of Medicine, Department of Internal Medicine, Istanbul, Turkey
}

Keywords: Malignant melanoma, magnetic resonance imaging, brain

Anahtar Kelimeler: Malign melanom, manyetik rezonans görüntüleme, beyin

\section{Dear Editor,}

A man aged 58 years who had been under follow up for malignant melanoma (MM) for six years, was admitted to the neurology outpatient clinic with symptoms of headache and loss of balance. He had had very severe and throbbing headaches for the last 3 days that were not accompanied by nausea and vomiting, and were not completely relieved by analgesics. He also reported loss of balance in the last 2 days, and he had difficulty in holding objects and climbing stairs. From his past medical history, it was learned that he had undergone surgery for MM located on the skin of left shoulder and a lung metastasis that was detected four months ago. On his neurologic examination, he had blurry papillary boundaries prominent on the right side and truncal ataxia. Contrast-enhanced brain magnetic resonance imaging revealed supra- and infratentorial multiple MM metastases that showed lesions in susceptibility weighted imaging (SWI) and VenBOLD sequences that were hyperintense on axial T1-weighted images and hypointense on axial T2-weighted images (Figure 1). Regression of lesions was observed following radiotherapy (Figure 2).

$\mathrm{MM}$ is in third place among tumors that metastasize to the brain (1). Although central nervous system metastases were detected in $10-40 \%$ of patients with MM in clinical trials, this rate was higher in an autopsy series (two thirds of patients) (2). Secondary spread of MM into the brain is often observed as multiple (3). The spread of brain metastases can be seen in various forms: the three most common forms are melanotic (hyperintense on T1-weighted images and hypointense on T2-weighted images), amelanotic (iso/ hypointense on T1-weighted images and iso/hyperintense on T2weighted images) and hemorrhagic (hypointense on T1-weighted images and hyperintense on T2-weighted images) (4).

The introduction of new sequences such as SWI in patients with MM, in whom brain metastases are commonly observed, provide significant contributions to the identification of subtypes of MM metastases and evaluation of the response to treatment.

Ethics

Informed Consent: Consent form was filled out by all participants.

Peer-review: Internally peer-reviewed.

Authorship Contributions

Surgical and Medical Practices: Ö.A.D., A.B., Concept: Ö.A.D., N.H.Y., Design: Ö.A.D., E.B., Data Collection or Processing: Ö.A.D., Analysis or Interpretation: Ö.A.D., G.A., Literature Search: Ö.A.D., N.H.Y., Writing: Ö.A.D.

Conflict of Interest: No conflict of interest was declared by the authors.

Address for Correspondence/Yazışma Adresi: Özge Arıcı Düz MD, Istanbul Medipol University Faculty of Medicine, Department of Neurology, Istanbul, Turkey Phone: +905053752680 E-mail: drozge2004@hotmail.com

Received/Geliş Tarihi: 08.09.2016 Accepted/Kabul Tarihi: 02.10.2016

${ }^{\circ}$ Copyright 2017 by Turkish Neurological Society

Turkish Journal of Neurology published by Galenos Publishing House. 

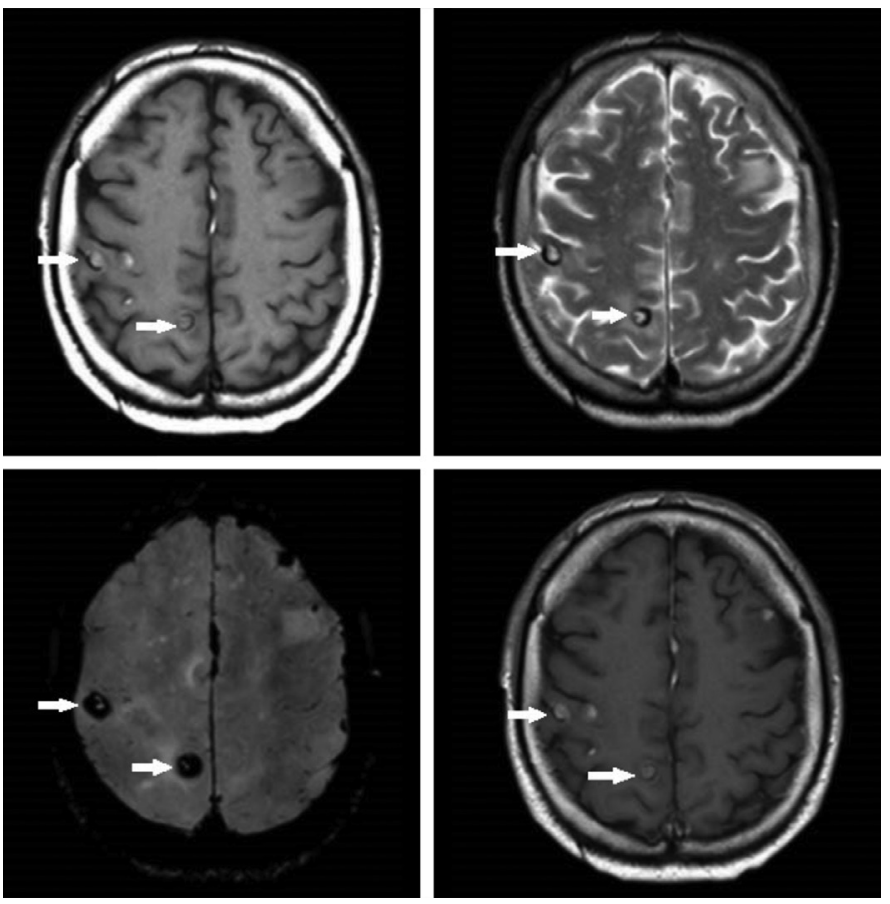

Figure 1. Supra- and infratentorial, multiple malignant melanoma metastases that showed susceptibility artifacts on VenoBOLD sequences that were hyperintense on axial T1-weighted images and hypointense on axial T2-weighted images

Financial Disclosure: The authors declared that this study received no financial support.

\section{References}

1. Schouten LJ, Rutten J, Huveneers HA, Twijnstra A. Incidence of brain metastases in a cohort of patients with carcinoma of the breast, colon, kidney, and lung and melanoma. Cancer 2002 15;94:2698-2705.
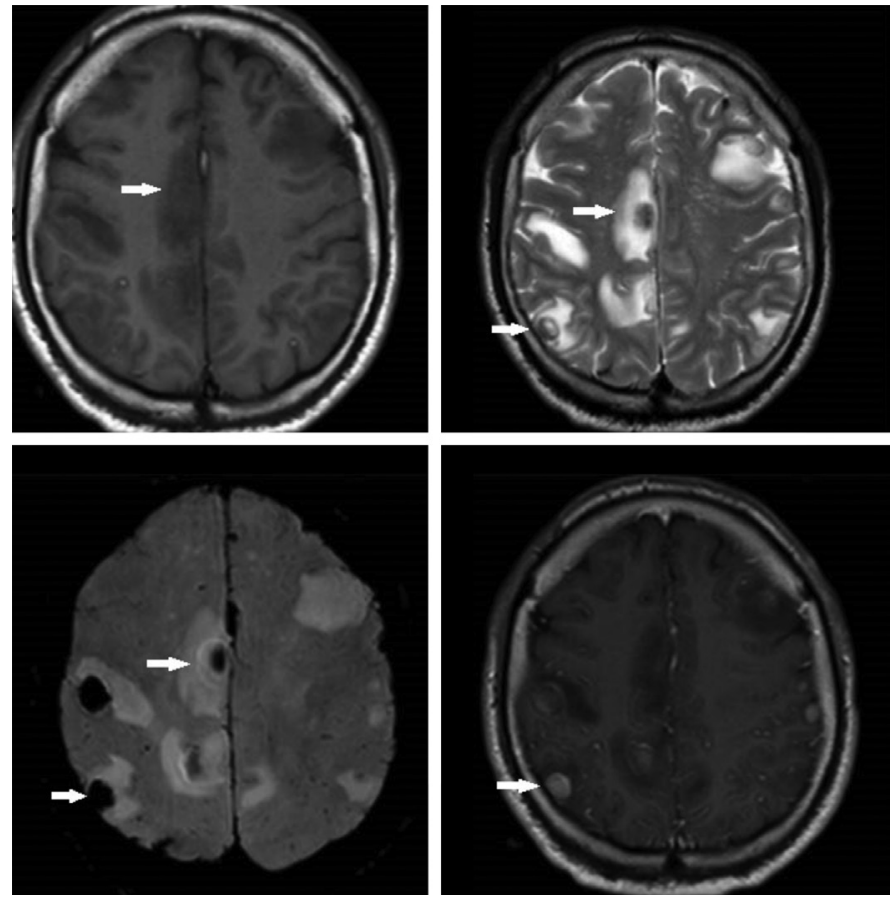

Figure 2. Numeric and dimensional regression in supra- and infratentorial, multiple malignant melanoma metastases on axial T1, T2, VenoBOLD and contrast-enhanced T1-weighted images.

2. Guzel A, Maciaczyk J, Dohmen-Scheufler H, Senturk S, Volk B, Ostertag CB, Nikkhah G. Multiple intracranial melanoma metastases: case report and review of the literature. J Neurooncol 2009;93:413-420.

3. Wronski M, Arbit E. Surgical treatment of brain metastases from melanoma: a retrospective study of 91 patients. J Neurosurg 2000;93:918.

4. Escott EJ. A variety of appearances of malignant melanoma in the head: a review. Radiographics 2001;21:625-639. 